\title{
Research on Environmental Cost from the Perspective of Coal-Fired Power Plant
}

\author{
Zehong Li ${ }^{1}$, Ting Fang ${ }^{1 *}$, Chen Chen ${ }^{2}$ \\ ${ }^{1}$ Department of Economics and Management, North China Electric Power University, Baoding, Hebei, China \\ ${ }^{2}$ State Grid Xiongan New Area Electric Power Supply Company, Xiongan New Area, Hebei, China
}

Received: 17 June 2020

Accepted: 11 August 2020

\begin{abstract}
Coal-fired power generation causes various resource and environmental problems. In order to alleviate the growing environmental problems, it is necessary for coal-fired power plants to carry out environmental cost management. This paper takes a coal-fired power plant in China as a research object to try to quantitatively evaluate various environmental costs of the power plant from a comprehensive perspective. First, the life cycle assessment (LCA) method was used to analyze the environmental impact of the operation of coal-fired power plants, thereby monetizing the external environmental costs of coal-fired power plants. Secondly, the environmental cost information embedded in coal-fired power plants in other general cost databases is classified to enable managers to obtain comprehensive environmental cost information. The results show that the environmental cost of coal-fired power plants is 24.81 yuan/GJ, of which the external environmental cost accounts for $55.93 \%$, the environmental prevention cost accounts for $41.8 \%$, and the environmental cost during the coal transportation stage is 4.9 yuan/GJ. Through quantitative analysis of environmental costs of thermal power generation enterprises, it can be seen that the environmental costs of coal-fired power plants during the transportation phase cannot be ignored, and should be included in the environmental cost accounting to avoid underestimating environmental costs. The results of this study can be used as a basis for internalizing environmental costs and for companies to carry out environmental cost management to encourage cleaner production and promote the sustainable development of thermal power generation companies.
\end{abstract}

Keywords: coal-fired power plants, environmental cost, life cycle assessment (LCA) method, quantitative evaluation, environmental management

\section{Introduction}

Coal-fired power generation is the dominant form of power generation in China. By the end of 2018, the

*e-mail: 821137790@qq.com installed capacity of coal-fired power was 1.14 billion $\mathrm{KW}$, accounting for $60.00 \%$ of China's national installed capacity [1]. However, coal-fired power generations inevitably bring environmental pollution problems, such as water pollution, noise pollution and air pollution $[2,3]$. In addition, coal-fired power generations can emit multiple pollutants which may lead to serious 
environmental deficiencies and human health issues. Consequently, the resource and environmental issues brought about by coal-fired power generations have arisen wide attention in China.

The environmental problems mentioned above are related to the entire process of coal-fired power generations. Although the coal production has been reduced recently, coal is still the dominant source for power generations. Due to current economic and technological constraints, coal-fired power generation in China will continue to exist for a long time [1]. Therefore, In order to alleviate the serious impacts of emissions from coal-fired power plants on environment and human health, it is imperative for administrators to conduct environmental cost analysis on coal-fired power plants to reduce harmful pollutants.

Over the last few years, although the government has implemented several environmental strategies, the short-term benefits preferred by the administrators of coal-fired power plants instead of environmentally sustainable approaches. The reasons for this circumstance are two-fold. On one hand, the indirect consequences of coal-fired power plants on environment are ignored in existing cost analysis approaches. On the other hand, because part of the environmental cost is embedded in other general cost databases, managers cannot obtain comprehensive environmental cost information, so it is difficult to compare shortterm and long-term benefits [4]. But modern society is seriously polluted, and attention should be paid to environmental impact while developing the economy. In the context of tackling climate change, relevant national laws and regulations set higher and higher environmental protection requirements for enterprises, and the environmental pressure on enterprises has increased sharply. At the same time, the development of new energy has also caused a huge impact on traditional coal-fired power generation. If coal-fired power generation companies want to develop better, they cannot only passively respond to the new national environmental protection regulations. They must start from within the company, pay attention to environmental protection, and pay attention to it. Environmental management to achieve a win-win situation between the economy and environmental protection. In addition, the company's environmental cost accounting can also appropriately reduce the tax burden. Hence, in order to control energy consumption and pollutant emission, environmental costs of coal-fired power plants over the entire life cycle should be comprehensively analyzed and accounted. As a consequence, the economic and social benefits of coal-fired power generations can be improved remarkably. Therefore, it is of great practical significance to systematically study environmental costs and corresponding impacting factors of coal-fired power plants.

The definition of environmental cost is proposed in 1998, which is the total cost of repairing environmental damage caused by production activities of enterprises and other related costs for achieving environmental goals [5]. Jo et al. [6] used a unique global data set to study how environmental costs affect corporate value, and found that companies can gain reputation and enhance corporate value by reducing environmental costs. Henri et al. [4] studied the relationship among the company's tracking of environmental costs (TEC), its environmental motivation, and its impact on environmental and economic performance from the concept and experience. Daher et al. [7] investigated the perceptions and preferences related to fuel consumption costs, greenhouse gas (GHG) social costs, and healthrelated air pollution costs, and the possible impact of this information on travel behavior. Su et al. [8] studied the impact of environmental commitments (general and cost-effective commitments) on the adoption of environmental management measures. Chen and Holden [9] summarized the environmental impact of Irish milk production through monetization to understand the environmental cost of Irish milk production.

The environmental cost of a coal-fired power plant includes four aspects, which are environmental maintenance cost, environmental prevention cost, resource consumption cost and environmental pollution loss cost. In specific, the environmental maintenance cost is the cost of eliminating pollutants to maintain environmental quality. Sewage charge is a typical kind of environmental maintenance cost. The environmental prevention cost refers to the cost associated with reducing pollutant emissions prior to the stage when coal-fired power plants pollute the environment [5]. The environmental prevention cost mainly includes the purchase cost and maintenance cost of environmental protection facilities as well as the wages of equipment operators. For product cost, some parts of natural resources consumed by coal-fired power plants are taken into account, while the other non-productive resources are not included. Therefore, the non-productive resource consumption cost should be considered in the environmental cost. The environmental pollution loss cost is also known as an external environmental cost, which refers to the economic loss caused by pollutant emissions from coal-fired power plants [10]. Specifically, as the environment and environmental functions are deteriorated by pollutant emissions, the adverse impact on society and other stakeholders can cause economic lossPollutant emissions from coal-fired power plants break the ecological balance and bring about various environmental problems, such as smog, acid rain, greenhouse effect. All these environmental damages should be compensated by coal-fired power plants, rather than other social entities. As sustainable development is promoting currently, the LCA method is recognized as an objective method to evaluate the environmental impact of coal-fired power plants. The LCA method can be used to systematically analyze the environmental performance of products or processes over their entire life cycle. In detail, the LCA helps to identify the environmental impact of a certain 
product not only during its production process and the acquisition of necessary raw materials but also during its exploitation and reprocessing [11]. Lelek et al. [12] demonstrated that the aim of adopting the LCA method on coal-fired power plants is to promote the sustainable development of coal-fired power generations by analyzing the environmental impacts quantitatively. After considering the energy consumption, resource consumption and pollutant emissions of various processes of coal-fired power plants, Cen et al. [13] applied LCA to compare three typical pollution control processes.

Some studies focus on the environmental impact of coal-fired power plants, particularly the greenhouse effect. Liang et al. [14] built a complete life cycle model for a coal-fired power plant. Based on the proposed model, concluding that sequestration technologies can reduce $\mathrm{CO}_{2}$ emissions. Odeh and Cockerill [15] explored the greenhouse effect of existing coal-fired power plants in the UK over their entire life cycles. Faaij et al. [16] combed the existing LCA literature to understand the potential environmental impact of the entire life cycle of fossil fuel power plants with carbon capture and storage. Steinmann et al. [17] proposed a new Monte Carlo simulation method to distinguish the uncertainty and variability of greenhouse gas emissions in the life cycle of coal-fired power generation in the United States. Some scholars have also calculated the external environmental costs of coal-fired power generation. Wang et al. [18] used the LCA approach to compare the external cost of coal-fired and biomass power plants. Georgakellos [19] used the global multi-regional MARKAL model to internalize the external costs of coal-fired power generation, arguing that structural changes in the power sector and fuel conversion have led to significant reductions in local pollution and carbon dioxide emissions worldwide. Mahapatra et al. [20] conducted a life cycle analysis (LCA) of the electricity production of the traditional coal-fired power generation system in Ahmedabad and assessed the external costs of coal-fired power generation. Rhodes et al. [21] developed a geographically-resolved method to calculate the leveled cost of electricity for new power plants on a county-by-county basis with estimations of several environmental externalities included. Wijaya and Bundit [22] analyzed the external environmental costs of PM10, $\mathrm{SO}_{2}, \mathrm{NO}_{\mathrm{x}}$ and $\mathrm{CO}_{2}$ from coal-fired power plants in Indonesia. For the purpose of studying the environmental impact of coal-fired power plants, Wang et al. [23] adopted the LCA method to calculate the external environmental costs. With the help of damage costs, Alnatheer [24] calculated the external environmental costs of coal-fired power plants in the United States and European countries.

From the above existing literature, attempts have been made to explore the environmental impact of coal-fired power plants. Nevertheless, there are still many research gaps. Firstly, most researches focus on a certain category of the environmental impact of coal-fired power plants, for example, the greenhouse effect. Secondly, most of the research is a macro analysis of the environmental costs caused by the entire process of power generation, but this does not apply to the internal environmental cost accounting of power generation companies. From the perspective of accounting of coal-fired power generation enterprises, the initial environmental cost of power generation should start from the coal transportation stage. Although the coal mining stage is the starting point of the life cycle of coal-fired power generation, such environmental costs in accounting are not attributed to power generation companies. Furthermore, most studies mainly focus on the calculation of external environment-related costs instead of the overall analysis of environmental costs of coal-fired power plants. However, environmental decisions made by coal-fired power plants not only need to consider external costs that are difficult to measure, but also depend on the overall environmental cost.

In order to fill the above research gap, this paper attempts to quantitatively analyze the overall environmental cost of coal-fired power plants from the perspective of accounting of coal-fired power plants. The main contributions are as follows:

(a) Starting from the accounting of power generation enterprises, the LCA index system of coal-fired power plants is constructed based on the LCA method, on the basis of which the negative impact on the environment during the operation of the coalfired power plants is monetized.

(b) Separating the environmental cost information embedded in the general cost database of coal-fired power plants, which allows managers to obtain comprehensive environmental cost information.

(c) Through analysis of various environmental costs of coal-fired power plants, the company puts forward measures to reduce environmental costs, and puts forward policy recommendations for reducing the environmental impact caused by coal-fired power plants.

\section{Data Collection}

This article takes a coal-fired power plant in China as a research object. Its annual power generation is 3.9 billion $\mathrm{K}$ Wh. About $4.8 \%$ of coal-fired power plants generate electricity for self-use. It is reported that the coal of the power plant is transported by rail. According to the China Communications Yearbook, my country's rail transport internal combustion engine consumes 24.9 kilograms of diesel fuel per 10,000 kilometers. According to statistics, about $1 \%$ of coal is lost due to wind and dust during coal transportation. The supporting environmental protection facilities of the power plant include wet limestone-gypsum desulfurization device (FGD) and electric dust collector (ESP). The initial investment, annual operation and 
Table 1. Basic situation of coal-fired power plant.

\begin{tabular}{|c|c|}
\hline Power plant characteristics & \\
\hline \multicolumn{2}{|l|}{ Power plant type } \\
\hline \multirow{3}{*}{ FGD } & Total investment, million yuan 541.96 \\
\hline & Operation and maintenance costs, million yuan 48.2858 \\
\hline & Useful life, year 30 \\
\hline \multirow{3}{*}{ ESP } & Total investment, million yuan 120.44 \\
\hline & Operation and maintenance costs, million yuan 8.0677 \\
\hline & Useful life, year 10 \\
\hline Rated power, MW & 600 \\
\hline Running time, $\mathrm{h} /$ year & 6500 \\
\hline Power output efficiency, $\%$ & 95.2 \\
\hline Coal consumption, $\mathrm{t} / \mathrm{year}$ & $165.05 \times 10^{4}$ \\
\hline \multirow{4}{*}{ Coal transportation } & Method rail transport \\
\hline & Distance, $\mathrm{Km} 1500$ \\
\hline & Fuel diesel \\
\hline & Loss, $\% 1$ \\
\hline Water consumption, $\mathrm{m}^{3} /$ year & $1021 \times 10^{4}$ \\
\hline Limestone consumption, $\mathrm{t} / \mathrm{year}$ & $1.35 \times 10^{4}$ \\
\hline \multirow{3}{*}{ Pollutant emissions, $\mathrm{Kg} /$ year } & TSP $697.01 \times 10^{4}$ \\
\hline & $\mathrm{SO}_{2} 63.38 \times 10^{4}$ \\
\hline & $\mathrm{NO}_{\mathrm{x}} 827.16 \times 10^{4}$ \\
\hline
\end{tabular}

maintenance costs and expected service life of the two types of equipment were obtained from field research. From the factory coal quality index, we can get preliminary information about the discharge of air pollutants. The relevant data involved in this study comes from field surveys of coal-fired power plants, environmental assessment reports of coal-fired power plants, China Statistical Yearbook and related literature. The specific data and parameters of coal-fired power plants are shown in Table 1. Using eBalance software to measure the external environmental cost of coal-fired power plants.

\section{Methodology}

The LCA method is one of the well-established methods to quantify various emissions, resource consumption, energy consumption and corresponding environmental impacts derived from the process of coalfired power plants. The advantage of the LCA method is that the method can not only analyze the production process but also the upstream and downstream stages analysis can be conducted.

In 1997, the International Organization for Standardization (ISO) divided the implementation procedure of LCA in ISO14040 into the following four steps: (a) goal and scope definition; (b) inventory analysis; (c) life cycle impact assessment; (d) result in interpretation.

In this paper, the purpose of using the LCA method is to calculate the external environmental costs of the coal-fired power plants by analyzing the environmental impact of inputs and outputs throughout the life cycle of coal-fired power plants. Moreover, the main focus of this study is to reduce environmental pollution from coal-fired power plants through comprehensive environmental cost accounting.

From the perspective of environmental cost accounting for coal-fired power plants, both the power generation stage and the coal transport stage should be included in the LCA for coal-fired power plants. The functional unit of this study is 1 GJ, while the scope of this paper covers the one-year operation of a coal-fired power plant.

The life cycle inventory analysis of coal-fired power plants deals with the issues of quantifying the physical material and energy flow for each subsystem in the life cycles of products. The types of resources and emissions involved in the life cycle inventory analysis of coal-fired power plants can be found in previous studies $[25,26]$. The input and output data displayed are 
Table 2 .Classification results and equivalent factors of coal-fired power plant.

\begin{tabular}{|c|c|c|c|c|}
\hline \multirow{2}{*}{ Emissions/Resources } & \multirow{2}{*}{ Unit } & \multirow{2}{*}{ Total } & \multicolumn{2}{|c|}{ Stage } \\
\hline & & & Coal transportation & Power generation \\
\hline Coal & $\mathrm{Kg}$ & 124.72 & 1.24 & 123.48 \\
\hline Diesel & $\mathrm{Kg}$ & 0.461 & 0.461 & \\
\hline Limestone & $\mathrm{Kg}$ & 1.01 & & 1.01 \\
\hline Water & $\mathrm{Kg}$ & 763.82 & & 763.82 \\
\hline Electricity & Kw.h & 14.04 & & 14.04 \\
\hline $\mathrm{CO}_{2}$ & $\mathrm{Kg}$ & 327.134 & $8.798 \times 10^{-2}$ & 327.046 \\
\hline $\mathrm{SO}_{2}$ & $\mathrm{Kg}$ & $4.884 \times 10^{-2}$ & $1.44 \times 10^{-3}$ & $4.74 \times 10^{-2}$ \\
\hline $\mathrm{CO}$ & $\mathrm{Kg}$ & $3.954 \times 10^{-2}$ & $2.47 \times 10^{-3}$ & $3.707 \times 10^{-2}$ \\
\hline $\mathrm{CH}_{4}$ & $\mathrm{Kg}$ & $2.231 \times 10^{-3}$ & $2.094 \times 10^{-5}$ & $2.21 \times 10^{-3}$ \\
\hline NMHC & $\mathrm{Kg}$ & $5.01 \times 10^{-3}$ & $5.758 \times 10^{-4}$ & $4.43 \times 10^{-3}$ \\
\hline $\mathrm{NO}_{\mathrm{x}}$ & $\mathrm{Kg}$ & 0.6213 & $2.47 \times 10^{-3}$ & 0.6188 \\
\hline $\mathrm{N}_{2} \mathrm{O}$ & $\mathrm{Kg}$ & $0.894 \times 10^{-3}$ & $1.42 \times 10^{-5}$ & $0.88 \times 10^{-3}$ \\
\hline TSP & $\mathrm{Kg}$ & 1.7953 & 1.2739 & 0.5214 \\
\hline COD & $\mathrm{Kg}$ & $1.25 \times 10^{-2}$ & & $1.25 \times 10^{-2}$ \\
\hline BOD & $\mathrm{Kg}$ & $9.55 \times 10^{-3}$ & & $9.55 \times 10^{-3}$ \\
\hline SS & $\mathrm{Kg}$ & $1.337 \times 10^{-2}$ & & $1.337 \times 10^{-2}$ \\
\hline $\mathrm{N}$ & $\mathrm{Kg}$ & $6.367 \times 10^{-3}$ & & $6.367 \times 10^{-3}$ \\
\hline $\mathrm{P}$ & $\mathrm{Kg}$ & $9.55 \times 10^{-4}$ & & $9.55 \times 10^{-4}$ \\
\hline Boiler ash & $\mathrm{Kg}$ & 23.49 & & 23.49 \\
\hline Desulfurization gypsum & $\mathrm{Kg}$ & 1.4214 & & 1.4214 \\
\hline Living garbage & $\mathrm{Kg}$ & $2.1845 \times 10^{-3}$ & & $2.1845 \times 10^{-3}$ \\
\hline
\end{tabular}

standardized data based on the functional unit. The life cycle inventory of the resource consumption and major emissions associated with coal-fired power plants is given in Table 2.

The procedure of the life cycle impact assessment is consists of three steps, which are classification, characterization and quantification [27]. The first step in the life cycle impact assessment is to classify resource consumption and major emissions into different environmental impact categories.

In the process of thermal power generation, a wide variety of pollutants will be produced, which will have varying degrees of impact on the environment. Pollutants mainly include slag, dust, waste gas, wastewater, etc. The flue gas contains a lot of harmful gases such as nitrogen oxides and sulfur dioxide. Nitrogen oxides can also form photochemical smog, which affects visibility and damages animals and plants. Denitrification equipment is set up for how to remove nitrogen oxides in the flue gas. Sulfur dioxide in the flue gas is an irritating sulfur oxide, one of the main pollutants in the atmosphere, and is listed as one of the three carcinogens lists by the World Health
Organization, which can cause direct or indirect harm to animals and plants. In this paper, according to the characteristics of coal-fired power plants, the environmental impact categories are divided into the following eight categories: (a) resource consumption; (b) global warming; (c) photochemical ozone creation; (d) acidification; (e) health hazard; (f) smoke and dust; (g) eutrophication; (h) solid waste. The classification results and equivalent factors [28] are listed in Table 3.

The second step is to use the equivalent factor for characterization. Each type of environmental impact has a number of corresponding environmental impact factors. In addition, the total contribution of these environmental impact factors is expressed by the environmental impact potential.

Therefore, the environmental impact potential of each type of environmental impact in the life cycle of coal-fired power plants is can be calculated as [23]:

$$
E P(j)=\sum E P(j)_{i}=\sum\left[Q(j)_{i} \times E F(j)_{i}\right]
$$

...where $i$ represents the $i$-th emission; $j$ is the $j$-th kind environmental impact category; $E P(j)$ represents 
Table 3. Classification results and equivalent factors.

\begin{tabular}{|c|c|c|c|c|}
\hline $\begin{array}{l}\text { Environment impact } \\
\text { category }\end{array}$ & Emissions/Resources & Primary standard & Equivalent coefficient of unit & Equivalent factor \\
\hline \multirow{5}{*}{ Resource consumption } & Coal & $\mathrm{Fe}$ & $\mathrm{Kg} \mathrm{Fe} / \mathrm{GJ}$ Material & 0.03 \\
\hline & Diesel & & & 1.35 \\
\hline & Limestone & & & 0.82 \\
\hline & Water & & & 0.0085 \\
\hline & Electricity & & & 0.098 \\
\hline \multirow{4}{*}{ Global warming } & $\mathrm{CO}_{2}$ & $\mathrm{CO}_{2}$ & $\mathrm{Kg} \mathrm{CO}_{2} / \mathrm{GJ}$ Emissions & 1 \\
\hline & $\mathrm{CO}$ & & & 2 \\
\hline & $\mathrm{CH}_{4}$ & & & 25 \\
\hline & $\mathrm{N}_{2} \mathrm{O}$ & & & 320 \\
\hline \multirow{3}{*}{$\begin{array}{l}\text { Photo chemical } \\
\text { Ozone creation }\end{array}$} & $\mathrm{CO}$ & $\mathrm{C}_{2} \mathrm{H}_{4}$ & $\mathrm{Kg} \mathrm{C}_{2} \mathrm{H}_{4} / \mathrm{GJ}$ Emissions & 0.03 \\
\hline & $\mathrm{CH}_{4}$ & & & 0.007 \\
\hline & NMHC & & & 0.398 \\
\hline \multirow{2}{*}{ Acidification } & $\mathrm{SO}_{2}$ & $\mathrm{SO}_{2}$ & $\mathrm{Kg} \mathrm{SO}_{2} / \mathrm{GJ}$ Emissions & 1 \\
\hline & $\mathrm{NO}_{\mathrm{x}}$ & & & 0.7 \\
\hline \multirow{3}{*}{ Health hazard } & $\mathrm{CO}$ & $\mathrm{CO}$ & $\mathrm{Kg} \mathrm{CO} / \mathrm{GJ}$ Emissions & 1 \\
\hline & $\mathrm{SO}_{2}$ & & & 100 \\
\hline & $\mathrm{NO}_{\mathrm{x}}$ & & & 65 \\
\hline Smoke and dust & TSP & TSP & Kg TSP/GJ Emissions & 1 \\
\hline \multirow{5}{*}{ Eutrophication } & $\mathrm{COD}$ & $\mathrm{NO}_{3}^{-}$ & $\mathrm{Kg} \mathrm{NO}_{3}^{-} / \mathrm{GJ}$ Emissions & 0.23 \\
\hline & BOD & & & 1.79 \\
\hline & SS & & & 0.86 \\
\hline & $\mathrm{N}$ & & & 4.43 \\
\hline & $\mathrm{P}$ & & & 32 \\
\hline \multirow{3}{*}{ Solid waste } & Boiler ash & Peat & Kg Peat/GJ Emissions & 1 \\
\hline & Desulfurization gypsum & & & 1 \\
\hline & Living garbage & & & 1 \\
\hline
\end{tabular}

the environmental impact potential of the $j$-th kind environmental impact category; $E P(j)_{i}$ is the $i$-th emission or resource contribution of the $j$-th kind environmental impact category; $Q(j)_{i}$ is the emission or consumption of the $i$-th emission or resource of the $j$-th kind environmental impact category; $E F(j)_{i}$ represents the equivalent factor of the $i$-th emission or resource of the $j$-th kind environmental impact category. Contributions of different emissions and resources as well as the contribution rates of environmental impact categories are presented in Table 4.

Quantification is a dimensionless comparison between the contribution of various types of environmental impacts and the overall environmental impact. With the help of weights, various types of environmental impact data can be further processed and analyzed to illustrate the relative environmental impact magnitude of each unit in the life cycle. The contribution rate of each environmental impact category is listed in Table 5.

The interpretation of results is the explanation of the results obtained from the life cycle inventory analysis and the impact assessment. As the environmental impact results from the life cycle analysis are not the main focus of this paper, the calculation of environmental costs of coal-fired power plants is investigated in detail.

\section{Results and Discussions}

In this study, the environmental prevention cost of the coal-fired power plant includes the investment cost of environmental protection equipment, operation cost and maintenance cost. 
Table 4. Contributions of different emissions and resources.

\begin{tabular}{|c|c|c|c|}
\hline Environment impact category & Emissions/Resources & Contributions & Contribution rates \\
\hline \multirow{5}{*}{ Resource consumption } & Coal & 3.74 & $28.7 \%$ \\
\hline & Diesel & 0.62 & $4.75 \%$ \\
\hline & Limestone & 0.828 & $6.34 \%$ \\
\hline & Water & 6.49 & $49.7 \%$ \\
\hline & Electricity & 1.37 & $10.51 \%$ \\
\hline \multirow{4}{*}{ Global warming } & $\mathrm{CO}_{2}$ & 324.134 & $99.896 \%$ \\
\hline & $\mathrm{CO}$ & 0.0262 & $0.008 \%$ \\
\hline & $\mathrm{CH}_{4}$ & 0.0275 & $0.008 \%$ \\
\hline & $\mathrm{N}_{2} \mathrm{O}$ & 0.286 & $0.088 \%$ \\
\hline \multirow{3}{*}{$\begin{array}{l}\text { Photo chemical } \\
\text { Ozone creation }\end{array}$} & $\mathrm{CO}$ & $0.39 \times 10^{-3}$ & $16.44 \%$ \\
\hline & $\mathrm{CH}_{4}$ & $0.0077 \times 10^{-3}$ & $0.32 \%$ \\
\hline & NMHC & $1.99 \times 10^{-3}$ & $83.24 \%$ \\
\hline \multirow{2}{*}{ Acidification } & $\mathrm{SO}_{2}$ & 0.0288 & $11.7 \%$ \\
\hline & $\mathrm{NO}_{\mathrm{x}}$ & 0.2174 & $88.3 \%$ \\
\hline \multirow{3}{*}{ Health hazard } & $\mathrm{CO}$ & 0.0131 & $0.057 \%$ \\
\hline & $\mathrm{SO}_{2}$ & 2.882 & $12.48 \%$ \\
\hline & $\mathrm{NO}_{\mathrm{X}}$ & 23.084 & $87.463 \%$ \\
\hline Smoke and dust & TSP & 1.7953 & $100 \%$ \\
\hline \multirow{5}{*}{ Eutrophication } & COD & $0.287 \times 10^{-2}$ & $3.18 \%$ \\
\hline & BOD & $1.71 \times 10^{-2}$ & $18.96 \%$ \\
\hline & SS & $1.15 \times 10^{-2}$ & $12.75 \%$ \\
\hline & $\mathrm{N}$ & $2.82 \times 10^{-2}$ & $31.27 \%$ \\
\hline & $\mathrm{P}$ & $3.05 \times 10^{-2}$ & $33.84 \%$ \\
\hline \multirow{3}{*}{ Solid waste } & Boiler ash & 23.49 & $94.28 \%$ \\
\hline & Desulfurization gypsum & 1.4214 & $5.705 \%$ \\
\hline & Living garbage & $2.184 \times 10^{-3}$ & $0.015 \%$ \\
\hline
\end{tabular}

The equation for calculating the investment cost which is included in the annual cost is as follows:

$$
\begin{aligned}
& T_{j}=F_{j}\left[\frac{i(1+i)^{n}}{(1+i)^{n}-1}\right] \\
& C_{1}=\sum \frac{T_{j}+M_{j}}{E}
\end{aligned}
$$

...where $F_{j}$ represents the total cost of $j$-th environmental protection equipment; $T_{j}$ represents annual average investment; $\frac{i(1+i)^{n}}{(1+i)^{n}-1}$ is inverse of ordinary annuity present value index; $M_{j}$ represents annual operation and maintenance cost; $E$ represents the annual power generation; $C_{1}$ represents the environmental prevention cost of the coal-fired power plant. For the case study, the environmental prevention cost of the practical coal-fired power plant is 10.37 yuan/GJ.

According to the "Standards and Calculation Methods for Pollution Discharge Charges", the exhaust gas discharge charges are levied in terms of pollution equivalents based on the type and quantity of pollutants discharged. In specific, the collection standard for each pollution equivalent is 0.6 yuan. Therefore, it can be calculated that the sewage charge of the practical power plant is 0.564 yuan/GJ.

The environmental loss cost is calculated by the shadow price method. The prices of resource consumption, air pollution, water pollution and solid waste pollution are presented in Table 6. Among the costs of resource consumption, coal has the highest consumption cost. Moreover, in terms of air pollution 
Table 5. The contribution rate of each environmental impact category.

\begin{tabular}{|c|c|c|c|c|c|c|}
\hline $\begin{array}{c}\text { Environment impact } \\
\text { category }\end{array}$ & $\begin{array}{c}\text { Environment } \\
\text { impact potential } \\
(\text { Kg/year })\end{array}$ & $\begin{array}{c}\text { Standard } \\
\text { benchmark } \\
\text { (Kg/year) }\end{array}$ & $\begin{array}{c}\text { Standardized } \\
\text { environmental } \\
\text { impact potential }\end{array}$ & Weigh & $\begin{array}{c}\text { Weighted } \\
\text { environmental } \\
\text { impact potential }\end{array}$ & $\begin{array}{c}\text { Contribution } \\
\text { rates }\end{array}$ \\
\hline Resource consumption & 13.048 & 13323.89 & $9.8 \times 10^{-4}$ & 0.381 & $0.37 \times 10^{-3}$ & $2.2 \%$ \\
\hline Global warming & 327.473 & 8700 & $3.76 \times 10^{-2}$ & 0.2003 & $7.53 \times 10^{-3}$ & $44.86 \%$ \\
\hline $\begin{array}{c}\text { Photo chemical } \\
\text { Ozone creation }\end{array}$ & $2.390 \times 10^{-3}$ & 0.65 & $3.67 \times 10^{-3}$ & 0.0846 & $0.31 \times 10^{-3}$ & $1.85 \%$ \\
\hline Acidification & 0.246 & 36 & $6.8 \times 10^{-3}$ & 0.0362 & $0.24 \times 10^{-3}$ & $1.43 \%$ \\
\hline Health hazard & 23.08 & 9100 & $2.5 \times 10^{-3}$ & 0.0846 & $0.21 \times 10^{-3}$ & $1.25 \%$ \\
\hline Smoke and dust & 1.79 & 18 & $9.97 \times 10^{-2}$ & 0.054 & $5.38 \times 10^{-3}$ & $32.06 \%$ \\
\hline Eutrophication & $9.07 \times 10^{-2}$ & 62 & $1.46 \times 10^{-3}$ & 0.1336 & $0.195 \times 10^{-3}$ & $1.16 \%$ \\
\hline Solid waste & 24.91 & 251 & $9.92 \times 10^{-2}$ & 0.0257 & $2.55 \times 10^{-3}$ & $15.19 \%$ \\
\hline
\end{tabular}

costs, the costs of $\mathrm{CO}_{2}$, TSP and $\mathrm{NO}_{\mathrm{x}}$ are relatively higher. Therefore, the reduction of $\mathrm{CO}_{2}$, TSP and $\mathrm{NO}_{\mathrm{x}}$ emissions of coal-fired power plants is essential. In the power generation process of coal-fired power plants, coal is included as a direct raw material in the product cost. However, for the environmental cost accounting, the other parts are not included in the resource consumption of the product. Calculation results of the environmental loss cost and the resource consumption environmental cost are presented in Table 7.

Table 6. Prices of emissions and resources.

\begin{tabular}{|c|c|c|c|c|}
\hline Environment impact category & Emissions/resources & $\begin{array}{l}\text { The price } \\
(\$ \cdot \mathrm{kg}-1)\end{array}$ & The cost & The proportion \\
\hline \multirow{5}{*}{ Resource consumption cost } & Coal & 0.095 & 11.85 & $95.11 \%$ \\
\hline & Diesel & 0.92 & 0.424 & $3.4 \%$ \\
\hline & Limestone & 0.023 & 0.0232 & $0.186 \%$ \\
\hline & Water & $0.21 \times 10^{-3}$ & 0.1604 & $1.28 \%$ \\
\hline & Electricity & $8.73 \times 10^{-5}$ & 0.00122 & $0.024 \%$ \\
\hline \multirow{8}{*}{ The cost of air pollution } & $\mathrm{CO}_{2}$ & $0.19 \times 10^{-2}$ & 0.6215 & $52.92 \%$ \\
\hline & $\mathrm{SO}_{2}$ & 0.44 & 0.0215 & $1.83 \%$ \\
\hline & $\mathrm{CO}$ & 0.018 & 0.0007 & $0.059 \%$ \\
\hline & $\mathrm{CH}_{4}$ & 0.049 & 0.000109 & $0.011 \%$ \\
\hline & NMHC & 0.34 & 0.0017 & $0.14 \%$ \\
\hline & $\mathrm{NO}_{\mathrm{x}}$ & 0.33 & 0.2050 & $17.45 \%$ \\
\hline & $\mathrm{N}_{2} \mathrm{O}$ & 0.91 & 0.0008135 & $0.08 \%$ \\
\hline & TSP & 0.18 & 0.3231 & $27.51 \%$ \\
\hline \multirow{5}{*}{$\begin{array}{l}\text { The cost of water } \\
\text { pollution }\end{array}$} & COD & $0.47 \times 10^{-3}$ & $0.5875 \times 10^{-5}$ & $29.25 \%$ \\
\hline & BOD & $0.47 \times 10^{-3}$ & $0.44885 \times 10^{-5}$ & $22.35 \%$ \\
\hline & SS & $0.47 \times 10^{-3}$ & $0.6284 \times 10^{-5}$ & $31.29 \%$ \\
\hline & $\mathrm{N}$ & $0.47 \times 10^{-3}$ & $0.299 \times 10^{-5}$ & $14.89 \%$ \\
\hline & $\mathrm{P}$ & $0.47 \times 10^{-3}$ & $0.0449 \times 10^{-5}$ & $2.22 \%$ \\
\hline \multirow{3}{*}{ The cost of solid waste pollution } & Boiler ash & $3.82 \times 10^{-3}$ & 0.0897 & $94.32 \%$ \\
\hline & Desulfurization gypsum & $3.82 \times 10^{-3}$ & 0.00543 & $5.21 \%$ \\
\hline & Living garbage & $3.82 \times 10^{-3}$ & 0.000008345 & $0.38 \%$ \\
\hline
\end{tabular}


Table 7. Cost and proportions of environmental loss costs and resource consumption environmental costs.

\begin{tabular}{|c|c|c|}
\hline $\begin{array}{c}\text { Environment impact } \\
\text { category }\end{array}$ & $\begin{array}{c}\text { The cost } \\
\text { (yuan/GJ) }\end{array}$ & The proportion \\
\hline Resource consumption & 5.036 & $36.3 \%$ \\
\hline Global warming & 4.328 & $31.19 \%$ \\
\hline $\begin{array}{c}\text { Photo chemical } \\
\text { Ozone creation }\end{array}$ & 0.028 & $0.2 \%$ \\
\hline Acidification & 0.7848 & $5.65 \%$ \\
\hline Health hazard & 0.8 & $5.77 \%$ \\
\hline Smoke and dust & 2.239 & $16.14 \%$ \\
\hline Eutrophication & 0.0001391 & $0.01 \%$ \\
\hline Solid waste & 0.659 & $4.74 \%$ \\
\hline
\end{tabular}

As can be seen from Table 7, the proportions of the resource consumption cost, the global warming cost, smoke and dust cost are 36.3\%, 31.19\% and 16.14\%, respectively. Furthermore, the calculated resource consumption environmental cost and the environmental loss cost are 5.036 yuan/GJ and 8.84 yuan/GJ, respectively. In summary, the total environmental cost of the practical coal-fired power plant is 24.81 yuan/GJ.

According to Table 8, the environmental cost during the coal transportation stage is 4.9 yuan/GJ. In specific, at the coal transportation stage, the resource consumption environmental cost accounts for the highest ratio which is $74.54 \%$. Similarly, the proportion of air pollution cost is $14.15 \%$. These costs cannot be ignored in the environmental management process of coal-fired power plants. Hence, in terms of accounting for the environmental costs of coal-fired power plants, the coal transport stage should be included in the power generation stage.

It can be seen from Fig.1 that the environmental loss cost, resource consumption cost, environmental prevention cost and environmental maintenance cost account for $35.63 \%, 20.3 \%, 41.8 \%$, and $2.27 \%$ of the total environmental cost, respectively. Apparently, the

\section{Environmental costs}

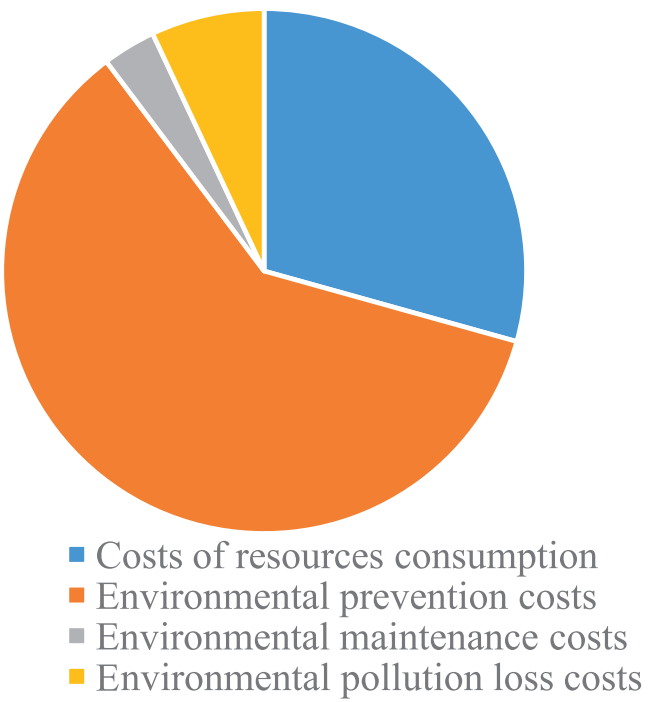

Fig. 1. Proportion of various environmental costs.

environmental loss cost has the second-highest ratio which is only lower than the environmental prevention cost. Nevertheless, the environmental loss cost is often ignored in the actual cost accounting of coalfired power plants which may lead to an inaccurate result. Furthermore, the environmental prevention cost accounts for the largest proportion of the total environmental cost of the practical coal-fired power plant which is $41.8 \%$. Therefore, measures should be taken to reduce the environmental prevention cost, such as improving the skill level of operators and scientific maintenance management of emission reduction equipment.

\section{Conclusions and Policy Implications}

This paper explores the environmental cost of coalfired power plants through the LCA method. According to the results obtained from LCA and cost analysis,

Table 8. Proportion of environmental costs at each stage.

\begin{tabular}{|c|c|c|c|}
\hline Environment impact category & The stage & The cost (yuan/GJ) & The proportion \\
\hline \multirow{2}{*}{$\begin{array}{l}\text { Resource consumption } \\
\text { environmental cost }\end{array}$} & Coal transportation & 3.75 & $74.54 \%$ \\
\hline & Power generation & 1.28 & $25 . .46 \%$ \\
\hline \multirow{2}{*}{ The cost of air pollution } & Coal transportation & 1.15 & $14.15 \%$ \\
\hline & Power generation & 6.98 & $85.85 \%$ \\
\hline \multirow{2}{*}{ The cost of water pollution } & Coal transportation & 0 & 0 \\
\hline & Power generation & $1.39 \times 10^{-4}$ & $100 \%$ \\
\hline \multirow{2}{*}{ The cost of solid waste pollution } & Coal transportation & 0 & 0 \\
\hline & Power generation & 0.659 & $100 \%$ \\
\hline
\end{tabular}


the environmental costs of coal-fired power plants are different at different stages throughout their life cycles. In addition, the resource consumption cost is the highest at the coal transportation stage, while the costs of air pollution, water pollution and solid pollution are relatively higher in the power generation stage.

In the life cycle of the practical coal-fired power plant, the environmental cost for 1 GJ of electricity generated is 24.81 yuan. In specific, the environmental prevention cost, the environmental loss cost, the resource consumption cost and the environmental maintenance cost are 10.37 yuan/GJ, 8.84 yuan/GJ, 5.036 yuan/GJ and 0.564 yuan/GJ, respectively. Moreover, the environmental costs for different types of environmental impacts are also different. From the calculation results for the environmental cost of the practical coal-fired power plant, it is found that the costs of the resource consumption, global warming, smoke and dust pollution are relatively high, where the corresponding proportions are $36.3 \%, 31.19 \%$, and $16.14 \%$, respectively. At present, coal-fired power generation is the dominant form of power generation in China. Inevitably, environmental pollution from coalfired power plants has become a major problem. The study in this paper provides a meaningful inspiration for mitigating the environmental impact of coal-fired power generation from the perspective of coal-fired power plants.

In the life cycle analysis of coal-fired power plants, it can be seen that the environmental cost of the coal transportation stage accounts for about $20 \%$ of the total environmental cost, which can not be ignored for an enterprise. However, in the current thermal power plant environmental cost accounting process, few companies have included it. This will lead to an underestimation of environmental costs and affect managers' environmental decisions. Therefore, for thermal power companies, when using environmental cost accounting methods, the coal transportation stage must be included.

Moreover, through analysis, it can be seen that environmental prevention costs account for $41.8 \%$ of environmental costs, which is the largest component of environmental costs. Coalfired power plants should eliminate backward technological processes and equipment, scientifically maintain environmental protection equipment, improve the skills of operators, and maximize the utilization rate of resources and energy consumption. Reduce environmental costs while protecting the environment.

According to the measurement and calculation of the cost for coal-fired power plants, it is found that the environmental lose cost accounts for a large proportion while the environmental maintenance cost accounts for a small proportion under the current sewage charging system. A major reason for this phenomenon is that the current pollution charging system standards in China may no longer solve the increasingly serious environmental problems. In specific, the current pollution charge is far lower than the actual environmental disruption cost and the practical environmental losses can not be compensated. Therefore, it is suggested for the policymakers that the pollution discharge charge should be increased the basis of the original standards.

Enterprises should develop an environmental performance appraisal system that is compatible with environmental cost accounting, so as to increase the company's emphasis on environmental costs. Enterprises can set up a dedicated environmental cost responsibility center, and an independent professional department is formed by professionals familiar with environmental information. Set the environmental protection standards that each department must strictly follow within the company, set evaluation rules, and incorporate the results of environmental activities into the evaluation, enhance the corporate staff's awareness of environmental evaluation crises, and improve the company's environmental cost control effect.

Furthermore, it is also found in the study that the external environmental cost of the practical coal-fired power plant is 8.84 yuan/GJ, which is often ignored in the existing cost accounting system due to the measurement difficulty. In other words, if a coal-fired power plant wants to adopt the environmental cost accounting, the cost will be inevitably increased and the profit will be decreased correspondingly. Therefore, in order to encourage the coal-fired power plant managers to voluntarily adopt the environmental cost accounting and environmental management as well as reduce environmental pollution from the source, it is suggested that the state guide the internalization of the external environmental costs of thermal power companies in a planned way. First, the government grants financial subsidies as appropriate. The government should encourage thermal power plants to adopt environmental cost accounting, and at the same time increase the grid price of power plants. For those thermal power enterprises that have adopted environmental cost accounting, the state should grant certain financial subsidies.Then, the government gradually canceled the subsidies as appropriate, and correspondingly increased supervision. On the basis that all power plants take the initiative to adopt environmental cost accounting, the subsidy measures are gradually eliminated. At the same time, supervision and media exposure are increased, and the invisible forces of society are used to jointly monitor the behavior of thermal power companies. At last, the government cancels subsidies and increases punishment. As China's power market becomes saturated, the government should increase the punishment of some small thermal power plants. It can also take hard measures such as shutdown to gradually cultivate a good and orderly competitive environment. Really transform the external environmental cost into the internal cost of the enterprise. At the same time, publicity and education related to environmental 
protection should be strengthened to raise awareness of environmental protection and awareness of environmental costs of the entire society.

\section{Conflict of Interest}

The authors declare no conflict of interest.

\section{References}

1. LI T., SONG Y.M., LI A., SHEN J., LIANG C., GAO M. Research on Green Power Dispatching Based on an Emergy-Based Life Cycle Assessment. Processes, 8 (1), 2020.

2. ANDRAE A.S. Comparative screening life cycle impact assessment of renewable and fossil power supply for a radio base station site. Int J Green Technol, 1, 258, 2015.

3. CRISTÓBAL J., GUILLN-GOS LBEZ G., JIMNEZ L., IRABIEN A. Optimization of global and local pollution control in electricity production from coal burning. Applied energy, 92, 369, 2012.

4. HENRI J.-F., BOIRAL O., ROY M.-J. The Tracking of Environmental Costs: Motivations and Impacts. European Accounting Review, 23 (4), 647, 2013.

5. ZENG L.-X., HE P., SHI J.-P. Problems and Countermeasures in Environmental Cost Accounting: A Case Study of China's Coal Industry. In: 2018 International Symposium on Hydrogen Energy and Energy Technologies. edn. Edited by Guo Y., 83, 2019.

6. JO H., KIM H., PAPK K. Environmental Costs and Firm Value. Asia-Pacific Journal of Financial Studies, 45 (6), 813, 2016.

7. DAHER N., YASMIN F., WANG M.R., MORADI E., ROUHANI O. Perceptions, Preferences, and Behavior Regarding Energy and Environmental Costs: The Case of Montreal Transport Users. Sustainability, 10 (2), 2018.

8. SU S., TUNG A., BAIRD K. The influence of environmental commitment on the take-up of environmental management initiatives. Australasian Journal of Environmental Management, 24 (3), 289, 2017.

9. CHEN W., HOLDEN N.M. Bridging environmental and financial cost of dairy production: A case study of Irish agricultural policy. Sci Total Environ, 615, 597, 2018.

10. LONG G., LEI W., SIJIE C., BO W. Research on Internalization of Environmental Costs of Economics. Ieri Procedia, 2 (Complete), 460, 2012.

11. DZIKUĆ M., PIWOWAR A. Life Cycle Assessment as an Eco-Management Tool within the Power Industry. Polish Journal of Environmental Studies, 24 (6), 2381, 2015.

12. LELEK L., KULCZYCKA J., LEWANDOWSKA A., ZAREBSKA J. Life cycle assessment of energy generation in Poland. International Journal of Life Cycle Assessment, 21 (1), 1, 2016.

13. CEN K. Comparative life cycle assessment and economic analysis of typical flue-gas cleaning processes of coal-fired power plants in China. Journal of Cleaner Production, 142, 3236, 2016.

14. LIANG X., WANG Z., ZHOU Z., HUANG Z., ZHOU J., CEN K. Up-to-date life cycle assessment and comparison study of clean coal power generation technologies in China. Journal of Cleaner Production, 39, 24, 2013.

15. ODEH N.A., COCKERILL T.T. Life cycle analysis of U.K. coal fired power plants. Energy Conversion and Management, 49 (2), 212, 2008.

16. FAAIJ A. Environmental impact assessment of CCS chains - Lessons learned and limitations from LCA literature. International Journal of Greenhouse Gas Control, 13 (Complete), 59, 2013.

17. STEINMANN Z.J.N., HAUCK M., KARUPPIAH R., LAURENZI I.J., HUIJBREGTS M.A.J. A methodology for separating uncertainty and variability in the life cycle greenhouse gas emissions of coal-fueled power generation in the USA. The International Journal of Life Cycle Assessment, 19 (5), 1146, 2014

18. WANG L., WATANABE T., XU Z. Monetization of External Costs Using Lifecycle Analysis - A Comparative Case Study of Coal-Fired and Biomass Power Plants in Northeast China. Energies, 8 (2), 1440, 2015.

19. GEORGAKELLOS D. Incorporating life cycle external cost in optimization of the electricity generation mix. Energy Policy, 65, 134, 2014.

20. MAHAPATRA D., SHUKLA P., DHAR S. External cost of coal based electricity generation: A tale of Ahmedabad city. Energy Policy, 49, 253, 2012.

21. RHODES J.D., KING C., GULEN G., OLMSTEAD S.M., DYER J.S. A geographically resolved method to estimate levelized power plant costs with environmental externalities. Energy Policy, 102, 491, 2017.

22. WIJAYA M.E., BUNDIT L. The hidden costs of fossil power generation in Indonesia: A reduction approach through low carbon society. Songklanakarin Journal of Science \& Technology, 32 (1), 2010.

23. WANG J., WANG R., ZHU Y., LI J. Life cycle assessment and environmental cost accounting of coal-fired power generation in China. Energy Policy, 115, 374, 2018.

24. ALNATHEER O. Environmental benefits of energy efficiency and renewable energy in Saudi Arabial"s electric sector. 34 (1), 2, 2006.

25. DONES R., HECK T., EMMENEGGER M.F., JUNGBLUTH N. Life Cycle Inventories for the Nuclear and Natural Gas Energy Systems, and Examples of Uncertainty Analysis (14 pp). International Journal of Life Cycle Assessment, 10 (1), 10, 2005.

26. HONDO H. Life cycle GHG emission analysis of power generation systems: Japanese case. Energy, 30 (11-12), 2042, 2005.

27. LIU J.-Y., QIAN Y., LI X.-X., HUANG Z.-X. Life cycle assessment of coal fired power generation and its alternatives. Journal of China Coal Society, 1, 2009.

28. WU M. The life cycle assessment of coal-fired power generation. Taiyuan University of Technology, Taiyuan: 74, 2011. 
